\title{
ADATBÁZIS ALAPÚ TECHNOLÓGIAI PARAMÉTER VÁLASZTÁS CAM RENDSZEREKBEN
}

\author{
Karker Lászlóa $^{a}$, Andó Mátyás $b^{b^{*}}$ \\ a ELTE, Informatikai Kar, Savaria Múszaki Intézet, Gépészmérnöki BSc, 3. évf. \\ ${ }^{b}$ ELTE, Informatikai Kar, Savaria Müszaki Intézet, egyetemi docens
}

\begin{abstract}
ABSZTRAKT
Korszerú CNC programozás során a CAM rendszer nem csak a szerszámpályát generálja automatikusan, hanem a forgácsolási paramétereket is kitölti. Edgecam szoftver esetén bemutatjuk, hogyan kell a háttér adatbázisokat létrehozni ahhoz, hogy a paraméterkitöltés optimális legyen a munkadarab anyagától, illetve a megmunkálástól függően. Megállapítottuk, hogy ez a módszer jelentôsen gyorsítja a programozást, illetve az elkészült programok megbízhatósága is javul. A forgácsolási körülmények optimálisak lesznek, elkerülhetők a szerszámtörések és javul a szerszám éltartama is. Univerzális lapkák alkalmazásával a szerszámmenedzsment hatékonyabbá válik és a termelékenység is nôhet, különösen akkor, ha a tervezési szempontoknál is figyelembe veszik az új programozási módszert.
\end{abstract}

Kulcsszavak: CAM, forgácsolási paraméterek, optimalizálás, adatbázis alapú automatizálás

\section{Bevezetés}

Manapság a termékek és a gyártás fejlesztése szempontjából a számítógépes tervezés és gyártás (CAD/CAM) jelentős szerepet játszik az ember és számítógép közötti interakcióban. A számítógépes technológia fố célja az, hogy egyszerúsítse a mérnöki munkát, ezáltal az emberek kitudják használni egyedi képességeiket, például a kreativitást és az innovációt [1].

A vállalatok egyre növekvô igénnyel szembesülnek az egyedi termékek, és a folyamatosan változó termékpaletta kezelése során. Ezáltal megnôtt a rendelésre történő gyártási rendszerek relevanciája. Egyre inkább kezdenek elterjedni, az olyan termékkonfigurációs rendszerek, amelyek akár kis darabszám esetén is lehetôvé teszik az egyes termékváltozatok hatékony gyártását [2]. A vállalkozások az egyéni vásárlókat a lehetô legrövidebb fejlesztési és gyártási idôvel, versenyképes költségek mellett kívánják kiszolgálni [3].

Korszerú CNC programozási környezetnek az a célja, hogy a gyártási folyamatok együtt fejlődjenek, a technológia által biztosított lehetőségekkel. Az új lehetőségek és módszerek egyre inkább hozzásegítenek a teljesen automatizált gyártási rendszer kiépítéséhez. Ezen belül az egyik cél, hogy az ember tévedését a folyamatból lehetôség szerint kizárjuk. A másik cél, hogy a technológia révén rendelkezésre álló lehetôségek között a változásokra minél gyorsabban reagálni tudjunk. A gyártási paraméterek asszociatív és éppen aktuális körülményekhez igazodó változtatása a CNC technológia egyik jelenkori kihívása. A nemzetközi verseny és a vevők gyors kiszolgálása arra ösztönzi a gyártókat, hogy az ipar 4.0 területtel egyre kiemeltebben foglalkozzanak. Magyarországon a CAM rendszerek használata nem csak kis- és középvállalkozásoknál, de nagyvállalatoknál sem elterjedt. A széria da-

(C) ELTE, Informatikai Kar, Savaria Múszaki Intézet, 2020

*Kapcsolattartó: am@inf.elte.hu

https://doi.org/10.37775/EIS.2020.1.4 
rabszámok csökkenése, a termékpaletta színesedése és a fejlesztési ciklusok felgyorsulása megköveteli a gyors CNC programozást is. Tömegtermelés esetén is törekednek arra, hogy sose legyen kiesett idő például pufferrel. Azonban hatékonyabb adatbázis alapú optimalizálással is elérhetô ez a cél. Ezzel a módszerrel az adott körülményekhez rendszerszintú optimummal történhet a gyártás (pl. költségre optimalizálással, gyártósorra optimalizálás), amely figyelembe veheti a rendelési állományt is.

Az esztergálás körülményeit elsősorban az előgyártmány és a szerszám befolyásolja anyagminőségtôl, forgácsoló lapkától, és késtípustól függóen. Ezen kívül a múvelet típusa is hatással van arra, hogy milyen paraméterek mellett érjük el az optimumot. A minôség, valamint gazdaságosság és forgácsképződés tekintetében kell a paramétereket meghatározni attól függően, hogy nagyolásról vagy simításról van szó. Célunk egy olyan adatbázis alapú paraméterillesztés kialakítása volt, amelyben ezektől a tényezôktől függően, a szoftver automatikusan tölti ki az optimális paramétereket.

\section{Anyag és módszer}

Munkánk első lépése, hogy a Vero Software EdgeCAM szoftverének ilyen célú lehetőségeit áttekintsük. Azonosítottuk azokat a funkciókat, amelyeket modernizált rendszerek esetén alkalmazni kellene automatikus ajánlásra. A feladatokat sorrendbe állítva megállapítottuk, hogy programozás szempontjából az előgyártmány és szerszám adatbázis létrehozásával érdemes kezdeni. Ennek megfelelóen létrehoztunk egy paraméterezett előgyártmány adatbázist, amelyben különbözô méretú nyersanyagokat helyeztünk el anyagminőségtôl függően. Ehhez társítottuk a rendelkezésre álló lapka készletet adott szerszámtár esetén. A váltólapkákhoz múvelet szerinti megkülönböztetéssel kapcsolatot hoztunk létre a lehetséges megmunkálási múvelethez tartozó optimális paraméterek között, illetve az alapanyag minősége között. Ezután a váltólapkát illesztettük a vele kompatibilis szerszámhoz, ahol külön figyelmet fordítottunk az univerzális lapka bevezetésének kérdéskörére, elönyeire is.

A létrehozott adatbázisból könnyen választhatunk szerszámot, amellyel a CAM rendszer kiszámolja a megmunkálási idôt. Így vizsgálni lehet, hogy a megmunkálás lehetséges alternatívái milyen időmegtakarítással járhatnak. Ezzel a funkcióval könnyebbé válik az optimalizálás és ki tudjuk szứrni az üresjáratokat, mindezt még a virtuális környezetben. Az adatbázisok nagyobb szerszám és lapkaflották kezelhetôségét is biztosítják. Rálátást kapunk a rendelkezésre álló szerszámokra, az adatbázisokban minden szükséges információt megkaphatunk az alkalmazott lapkáról.

\section{Megvalósítás}

Létrehoztunk egy előgyártmány-adatbázist, de ahhoz, hogy ez különböző anyagoknál múködőképes legyen készítettünk anyagadatbázist is a háttérben (1. ábra). Előgyártmány létrehozásánál a ren-

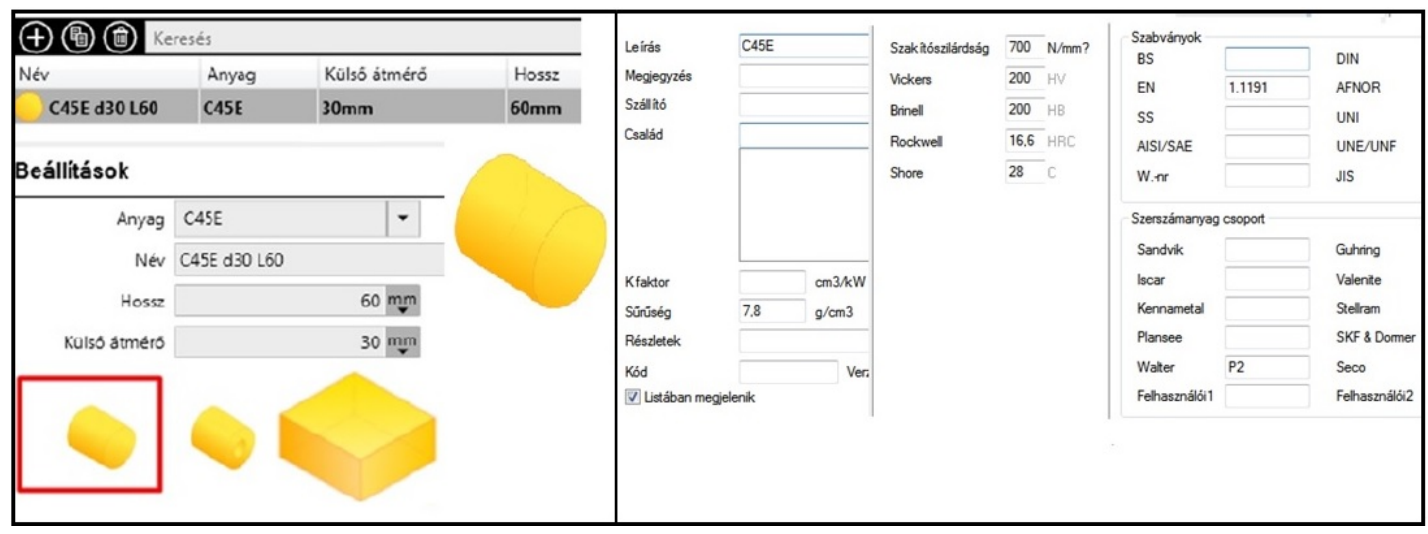

1. ábra: Előgyártmány-adatbázis (baloldalon) és anyagadatbázis (jobboldalon) 


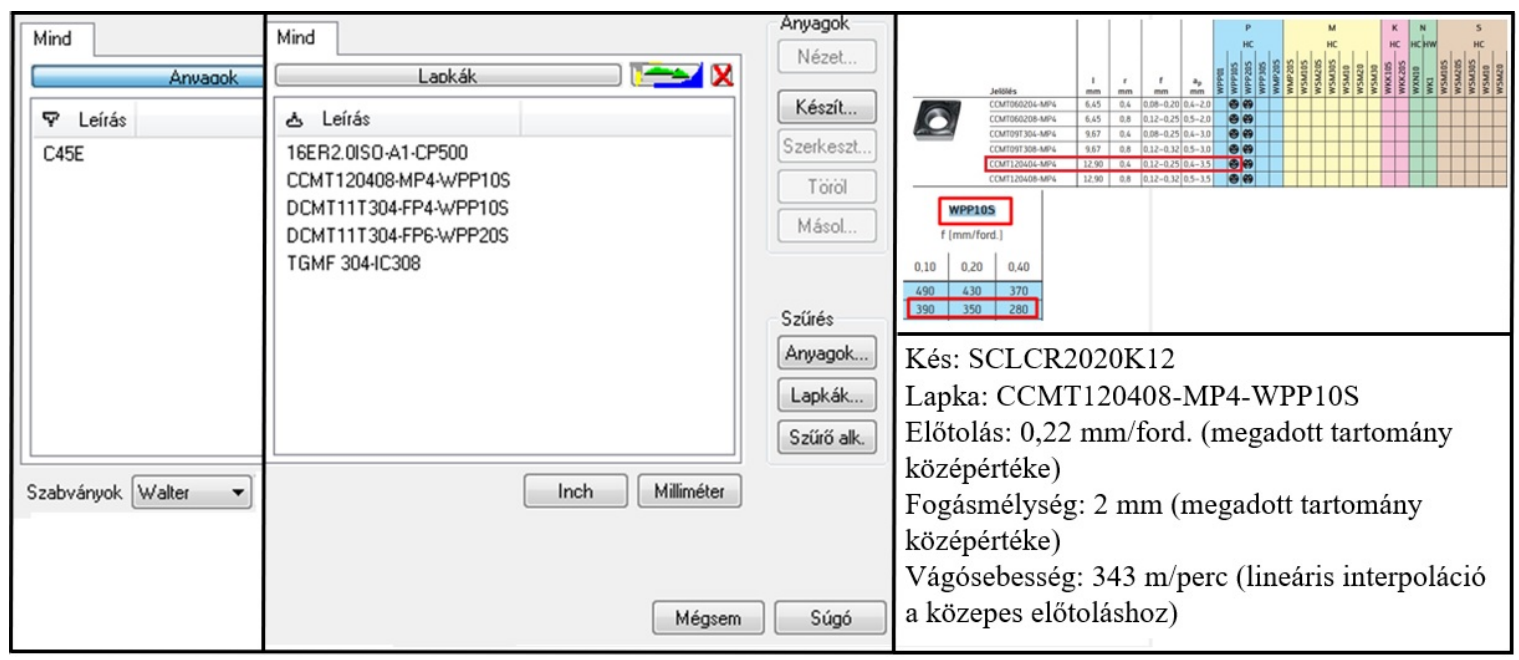

2. ábra: Létrehozott lapkaflotta és anyagminőség hozzárendelés, lapkaválasztás példa

delkezésre álló geometriát választottuk ki, majd az anyagadatbázisból hozzárendeltük a létrehozott alapanyagot. A lapkaflotta elkészítéséhez a Walter fókatalógust használtuk [4], onnan választottunk a konkrét szerszámokat: nagyoló, simító, beszúró, menet, valamint múvelet tekintetében univerzális szerszámot.

A katalógusból választott lapkákat összekapcsoltuk a velük megmunkálható anyagokkal. A 2. ábra jobb oldalán látható a katalógusból történô választásra egy példa (nagyoló lapka). A lapkáknál megállapítottuk a forgácsolási paramétereket. A gyártó által megadott tartománynak a középértékét választottuk, a hosszabb éltartam miatt. A paramétereket kigyújtöttük külön alapanyagokhoz, rendre nagyoláshoz és simításhoz is. A 3. ábrán éppen általános esztergálás látható, ami a szoftverben nagyoló múveletet jelent. A szerszámtár létrehozása után a fentebb létrehozott adatbázisokból a lapkákat hozzárendeltük a szerszámokhoz (4. ábra). Itt be kell állítani azokat a lehetséges anyagokat, amelyeket az adott szerszámmal meg lehet munkálni. Ezzel tulajdonképpen a háttérmunka elkészült, és ezentúl a szoftver automatikusan kitölti a forgácsolási paramétereket a múveleteknél.

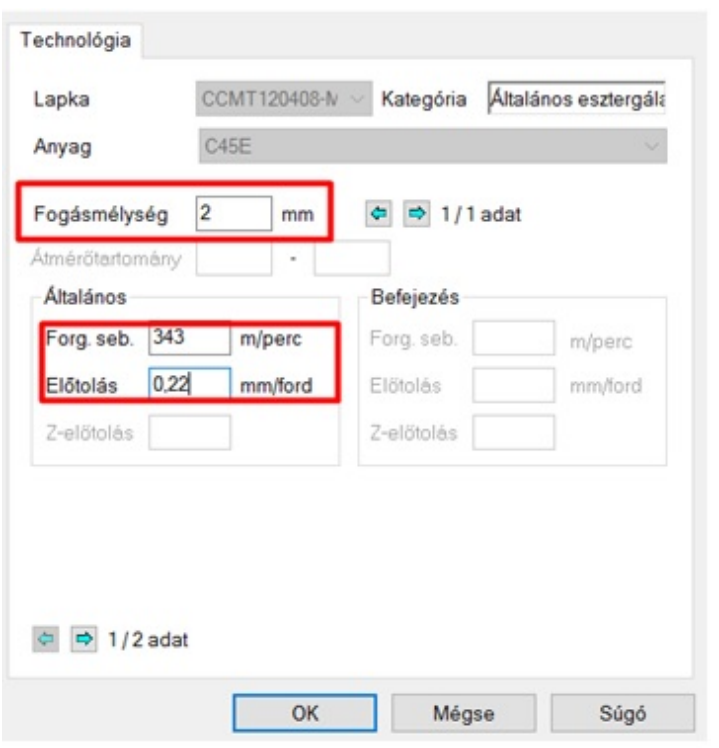

3. ábra: Forgácsolási paraméterek és múvelet típus hozzárendelése a nagyoló lapkához 


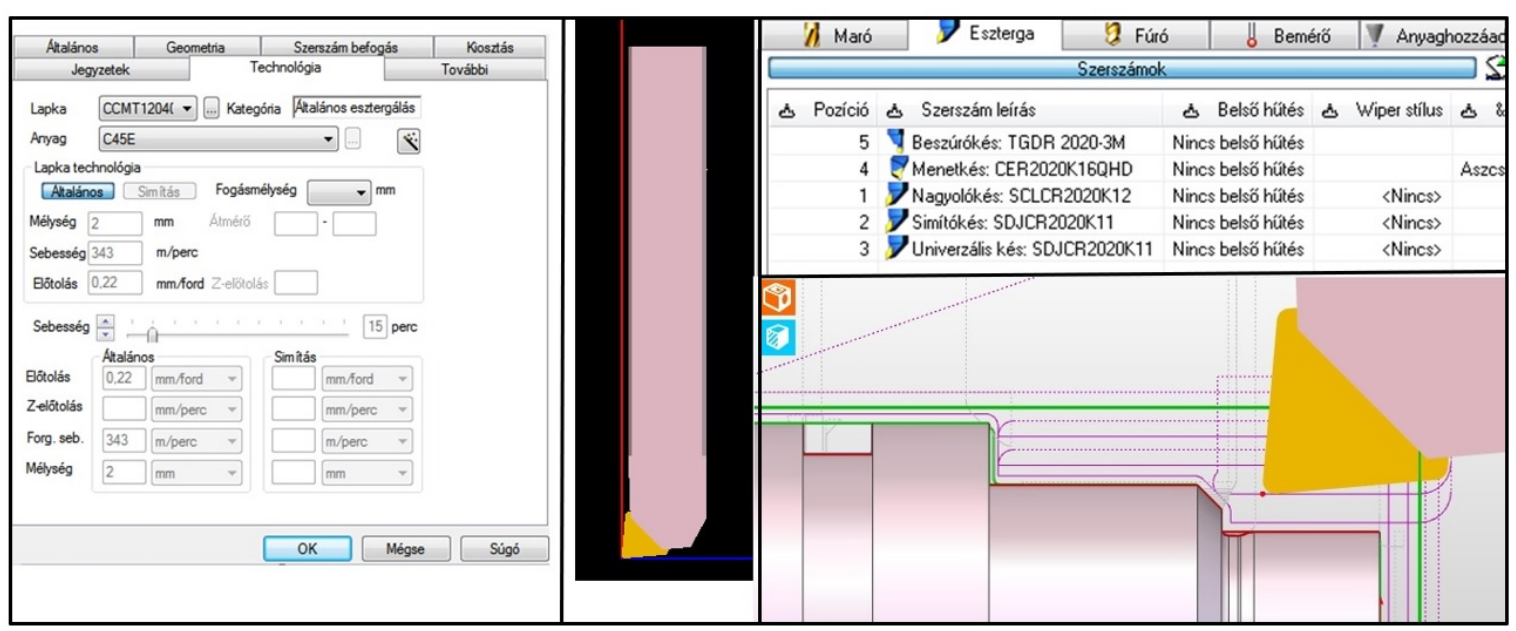

4. ábra: A szerszámtár az adatbázisból feltöltött adatokkal

\section{Univerzális lapkák alkalmazása}

Egyedi- és kis sorozatoknál, de speciális esetben nagy sorozatnál is optimális lehet kevesebb szerszámmal dolgozni. Tipikus eset, ha a simítás nem igényel kiváló felületi minőséget, vagy ha a szerszám beszerzése és a szerszámcserével töltött idő gazdaságilag indokolatlanná teszi a célirányosan optimalizált lapka használatát (például a megmunkálási idő nem lesz számottevôen rövidebb). Általános megoldás ezekben az esetekben, hogy univerzális szerszámot alkalmaznak. Jellemzően minden gyártónak van olyan forgácstörő geometriája, illetve bevonati minősége, amely általánosan jó forgácsképzôdést eredményez. Univerzális lapkák közül két fố típust különböztethetünk meg. Az egyiket széles körben használhatjuk különféle alapanyagokhoz, a másikat pedig több fajta múveletre is használhatjuk (nagyolás, simítás), mert széles forgácsolási tartományban eredményez jó forgácstörést. Ebben az esetben jellemzóen meghatározott anyagcsoportokat munkálhatunk meg. Az adott megrendelés állomány esetén könnyen eldönthető, hogy melyik irányvonal lehet optimális a vállalkozás számára.

Ilyen a WALTER által fejlesztett Tiger-tecR lapkacsalád. Hagyományosnál nagyobb univerzális forgácstörési tartománnyal rendelkeznek. Nagyobb forgácsolási sebesség az új, optimalizált mikrostruktúrájú alumínium-oxiddal (más gyártóknál is kapható) érhető el. Az új mechanikus utókezelésnek köszönhetően nagyobb folyamatbiztonság és hosszabb éltartam érhető el [5]. A kopásállóság és a szívósság ideális kombinációja biztosítja a lapkák hosszú éltartamát. Általánosan megállapítható, hogy a kopásállóság a keménységgel együtt nô, azonban ezzel párhuzamosan csökken a lapka szívóssága. Ez a fơ oka annak, hogy egy lapkával nem lehet minden anyagot, bármilyen múvelettípust és körülményt lefedni. Vagyis univerzális lapkával jellemzően nem optimális a forgácsolás és ennek az egyre nagyobb sorozatoknál van jelentősége.

Univerzális lapkák alkalmazása például célgépgyártásnál kifejezetten gazdaságos lehet, ha a tervezési szempontok közé beemelik a rendelkezésre álló szerszámkészletet. Ebben az esetben a szerszámkészlet drasztikusan csökkenthetô (a felszabaduló erôforrás másra használható), a programozás automatizálható és jelentôsen gyorsítható, miközben a megmunkálási idő gyakorlatilag változatlan marad, vagy adott esetben csökken. Fontos jellemző, hogy egyedi gyártásnál az alkatrész megmunkálási idejében több időt tehet ki a gép felszerszámozása, mint maga a forgácsolás.

Univerzális lapka használatához érdemes a gyártási/tervezési szokásokat úgy alakítani, hogy meghatározott legyen például a minimális belsô éltompítás, az elérhető felületi minôség esetleges kúpos felületek szögei (esztergálásnál). Az ilyen múveletre vagy anyagminőségre univerzális lapkáknál megoldható, hogy adatbázis alapú paraméterválasztást alkalmazzunk, gyakran változó termékpaletta 


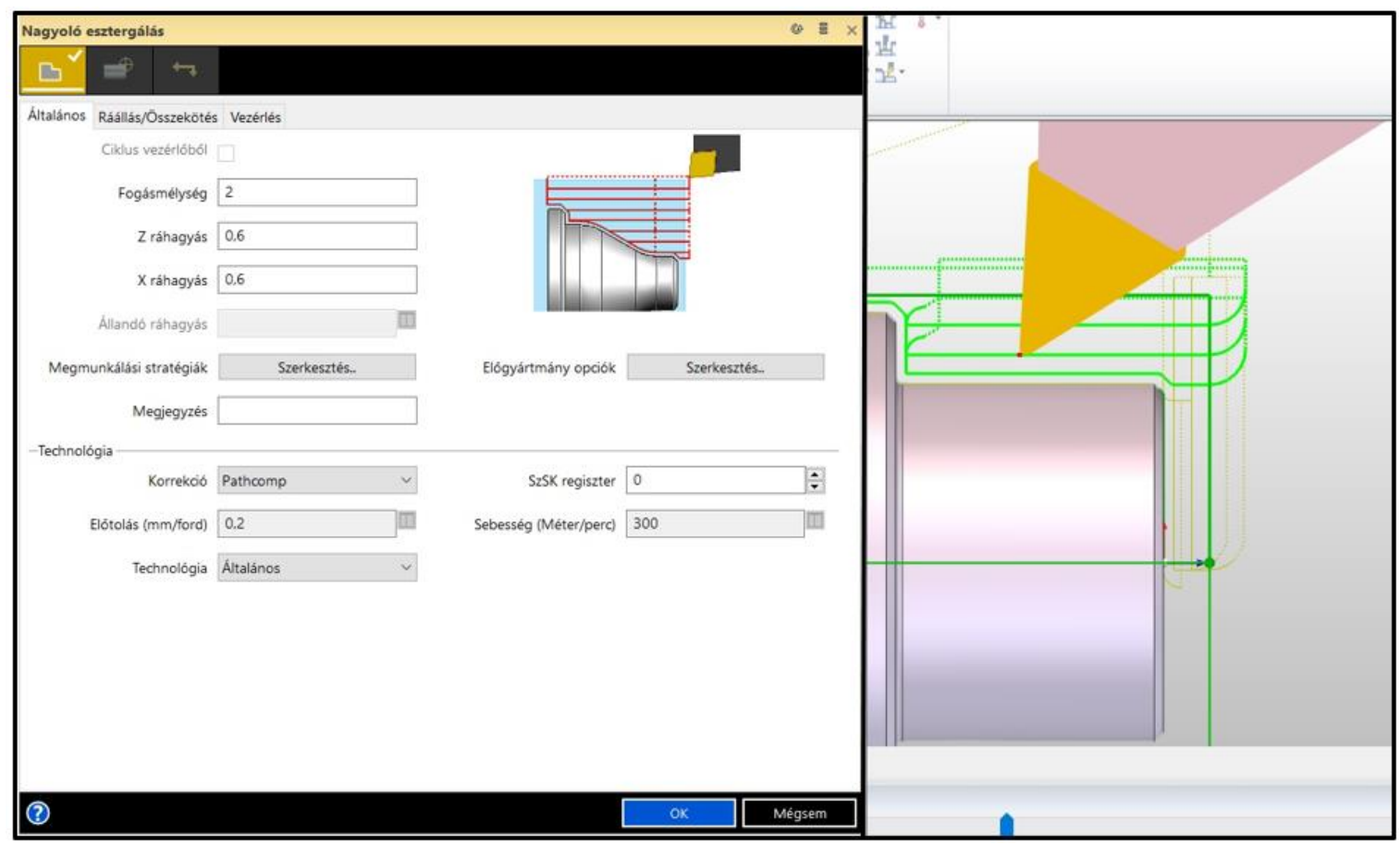

5. ábra: Univerzális szerszám a nagyoló múvelethez, az automatikusan kitöltött paraméterekkel

ellenére is. Adott lapka estén az adatbázisba több paraméter kombináció is bevihetô, ebból kifolyólag egyszer kell a lehetséges eseteket meghatározni. Minden esetleges termékváltoztatásnál a program frissítése automatikusan a megfelelő esethez tartozó paraméterekkel tölti fel a forgácsolási paramétereket.

\section{Az új rendszer alkalmazása}

Az adatbázisok alapján a lehetséges szerszám/szerszámok automatikusan behívhatóak vagy leszűrhetőek az alkatrészhez. Ez az elsődleges szúrés, ami a múvelet fajtája (pl. beszúrás, menetelés) és típusa (nagyolás vagy simítás) alapján történik. A szoftver az adatbázis alapján az anyagminôségnek és mûveletnek megfelelően kitölti a forgácsolási paramétereket. Az 5. ábrán az univerzális szerszám alkalmazása látható nagyoló megmunkálásnál. A 6. ábra azt mutatja, hogy ugyanazon univerzális szerszámhoz simító megmunkálásnál már más paramétereket tölt ki a szoftver, hiszen a kezdeti feltételek is mások lettek.

\section{Eredmények}

A létrehozott adatbázisok alkalmazásával adott alkatrésznél a szoftver a használt alapanyag alapján azokat a szerszámokat ajánlja fel, amelyekkel az adott anyagminőség megmunkálható. Így nem történhet olyan hiba, hogy alumínium forgácsolási paramétereivel acél alkatrészt munkálunk meg, módosítás esetén. Nem kell a paramétereket minden egyes változás esetén felülbírálni, elég egyszer feltölteni az adatbázist a rendelkezésre álló szerszámoknál. Ha meghatároztuk az optimális gyártási paramétereket, akkor azok kitöltése automatikussá válik, így az új alkatrészek gyártásánál elkerüljük a paramétertévesztésból adódó szerszámtöréseket.

A programozási idő jelentôsen lecsökken azáltal, hogy egy alkatrészhez a szerszámtárból csak az ott felhasznált szerszámot társítjuk. Ezáltal minden múvelethez csak egy-két darab szerszám válaszható. Teszteléseink alapján a programozás egy nagyoló és simító múvelet esetén 15 darab billentyúleütéssel és 17 darab kattintással rövidül le, mert a szoftver a múveletek programozásánál automatikusan 


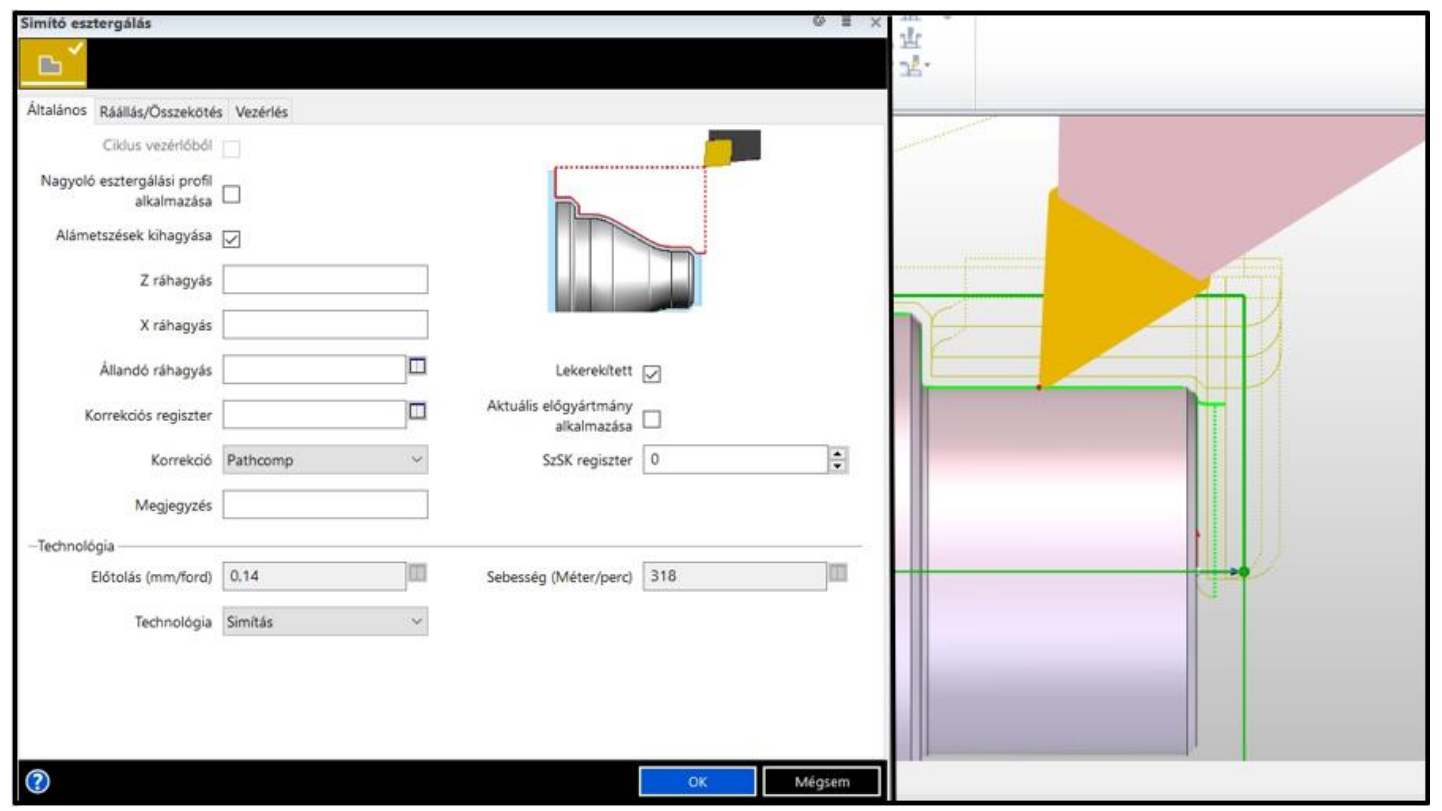

6. ábra: Univerzális szerszám a simító mûvelethez, az automatikusan kitöltött paraméterekkel

behívja a múvelethez tartozó paramétereket. Ez azzal a hatással is jár, hogy a programozónak nem kell a katalógusból választani (vagy egy korábbi programban megkeresni) paramétereket, elég a múveleti sorrendre összpontosítania. Ezzel szintén jelentős idő takarítható meg.

CAD/CAM rendszerek használata esetén az asszociativitás miatt eleve könnyebb a változások nyomon követése. Adatbázis alapú paraméter kitöltés esetén a gyártási paraméterek függnek az alapanyagtól, így pár kattintással az egész megmunkálási program átalakítható az új anyagra. Ebben az esetben is fontos szempont, hogy az üzembiztonság lényegesen jobb, mert minden paraméter automatikusan megkapja a megfelelő értéket. Ráadásul mindezt úgy, hogy a forgácsolási teljesítmény is optimális marad.

Az adatbázisok alkalmazása nagy szerszámtárak esetén elengedhetetlen. A létrehozott adatbázisban szưréseket végezhetünk akár forgácsolási paraméter, gyártó, vagy pedig alkalmazástípus szerint, ezen belül még múvelettípus szerint is. Ez hozzájárul ahhoz, hogy a raktárkészlet-menedzsment is optimálisan múködjön, tényadatokra támaszkodjon. Ebben az esetben elkerülhetôvé válik a szerszámhiányból adódó kései megrendelés teljesítés is.

\section{7. Összefoglalás}

Programozási idők csökkennek az adatbázisokat felhasználva. A továbbiakban az egyes paraméterek átmásolása táblázatból/honlapról nem szükséges. Az adatbázisból mindig felülíródik a korábban bevitt paraméter, így rossz érték nem maradhat a rendszerben (pl. alumínium után acél megmunkálása). A változások gyors és automatikus kezelése (modell, anyag, geometria, technológia, stb.) megtörténik. Egyszeri időráfordítással kell csak felvinni a használt szerszámok paramétereit. A programozónak csak a múveleti sorrenddel kell foglalkoznia, nem zökkenti ki a paraméterek keresése a munka folyamatából.

Univerzális lapkát alkalmazva jelentôsen megnőhet a hatékonyság, főleg ha a tervezésnél is szempont lesz ez a filozófia. Nagyobb szerszámtárak kezelhetôvé válnak az adatbázis alkalmazásával. Rálátást kapunk folyamatainkra a CAM környezettel, így lehetséges a paraméterek könnyebb optimalizálása és azok ellenőrzése, valamint a forgácsolási paraméterek automatikus illesztése. 
Továbblépésként ezt az adatbázist akarjuk összekapcsolni a stratégia kezelő alkalmazásával, mely az előre beprogramozott mérnöki intelligencia segítségével gyakorlatilag pár kattintással létrehozza a teljes megmunkálási programot. Ebben az igazi kihívást az alkatrészcsaládokra érvényes mérnöki intelligencia megalkotása és beprogramozása jelenti. Az átfutási idő, a költségek csökkentése és a minôség továbbfejlesztésének nagy lehetőségeit kínálja az egyes CNC programok automatikus generálása [2].

\section{Köszönetnyilvánítás}

Az ED_18-1-2019-0030 szerződésszámú projekt (Alkalmazásiterület-specifikus nagy megbízhatóságú informatikai megoldások tématerület) a Nemzeti Kutatási Fejlesztési és Innovációs Alapból biztosított támogatással, a Tématerületi kiválósági program támogatásával valósult meg.

\section{Irodalomjegyzék}

[1] Y. Li, M. Hedlind, T. Kjellberg, Usability Evaluation of CADCAM: State of the Art, Procedia CIRP 36, 2015, pp. 205-210 CrossRef

[2] C. Schaede, S. Seifermann, J. Metternich, Automated generation of CNC programs for manufacturing of individualized products, Procedia CIRP 72, 2018, pp. 1251-1257 CrossRef

[3] P.K. Paritalaa, S. Manchikatlab, P.K.D.V. Yarlagaddaa, Digital Manufacturing- Applications Past, Current, and Future Trends, Procedia Engineering 174, 2017, pp. 982-991 CrossRef

[4] WALTER: Fókatalógus, 2017, Walter Deutschland GmbH Eschborner Landstr. 112D-60489 Frankfurt(A 126, A238, B 506.oldal)

[5] WALTER: Esztergálási kézikönyv - TIGER-TEC@ SILVER - ISO P generation, 2012, Walter Deutschland GmbH Eschborner Landstr. 112D-60489 Frankfurt (2, 4, 6, 14. oldal) 